\title{
EL FATAL DESTINO DE ROMA (2019)
}

Kyle Harper. Editorial Crítica.

doi: https://doi.org/10.26439/en.lineas.generales2021.n5.5426

\author{
Martín Mac Kay Fulle \\ Universidad de Lima
}

Publicado originalmente en inglés en el 2017 y traducido dos años después al español, El fatal destino de Roma es una obra que nos da nuevas perspectivas de la desaparición de uno de los imperios más grandes y prósperos de la historia, la Roma de los césares. Sumando a los ya conocidos motivos de su decadencia y derrumbe, como lo son las luchas internas, la corrupción del Estado, las invasiones bárbaras y la aparición del cristianismo, el doctor en historia Kyle Harper nos muestra un motivo mucho más importante para entender el fin del Imperio romano occidental: un mundo mediterráneo interconectado artificialmente por la expansión romana a otros rincones del planeta, que incluyeron zonas limítrofes a amplias selvas tropicales vírgenes en un momento de cambio climático denominado "el fin del Holoceno".

En el primer capítulo de su obra, titulado "Medio ambiente e imperio", Harper nos explica de manera sencilla cómo se dio la expansión del imperio a través de la negociación de la élite de la Ciudad Eterna con las de las provincias sometidas, y cómo esta alianza llevó a un crecimiento económico y demográfico nunca antes visto en sociedades preindustriales. Así, necesitaron apoderarse de más tierras para la producción de alimentos para su población, así como la generación de impuestos que tendría por finalidad la manutención del gigantesco aparato estatal. Dicha expansión y auge del Imperio romano estuvieron asociados a un óptimo estado climático entre los años 200 a. C. y 150 d. C., que generó la prosperidad de la maquinaria agrícola.

Posteriormente, explica el autor, Roma sufre los embates de las invasiones de pueblos venidos del norte y del este de Europa, además de sus guerras internas en el momento en que se inicia un periodo de transición que culmina con una pequeña era del hielo entre 450 y 700 d. C. Estos doscientos cincuenta años coinciden con la peste antonina (165 d. C.), la peste de Cipriano (249 d. C.) y la peste de Justiniano (541 d. C.). La primera de ellas fulminó a por lo menos siete millones de ciudadanos del imperio, la segunda mató a un promedio de cinco mil personas al día en la ciudad de Roma, mientras la tercera liquidaba diariamente a diez mil personas en Constantinopla. Las preguntas que se dejan momentáneamente en el tintero son estas: ¿existe una relación entre los cambios climáticos y las mencionadas pestes o pandemias?, ¿qué relación hay entre la expansión del imperio y la aparición de dichas pestes? 
"La época más feliz" es el nombre del segundo capítulo; aquí Harper describe cómo el Estado imperial logró un equilibrio entre la maquinaria fiscal y la maquinaria militar para establecerse como la potencia más importante de la Antigüedad, una potencia que en territorios ubicados en tres continentes pudo superar la común mortalidad de su tiempo y crear grandes centros urbanos en donde la explosión demográfica se hizo notable: la media era de seis hijos por mujer. En tiempos del emperador Marco Aurelio, el imperio llegó a controlar a 75 millones de personas, es decir, una cuarta parte de la población del planeta, en donde la mayoría de los habitantes tenían un ingreso que aumentaba más rápido que el costo de alimentos y alquileres. El nivel de desarrollo llegó a tal punto que durante el siglo II una quinta parte de la población vivía dentro de las grandes urbes del imperio bajo el cobijo de un comercio global floreciente y avances tecnológicos agigantados.

Todo este contexto construido se potenció aún más con el llamado "óptimo climático romano", un momento en que la estabilidad de climas templados y húmedos incrementó la producción agrícola, lo cual fue beneficioso para las arcas del Estado y el sentir de la población. Una combinación de calor y aumento de lluvias favoreció la avanzada de población y obras urbanísticas a territorios vírgenes o marginales, pero a su vez acercó a dicha población hacia peligrosos elementos de la naturaleza, como son ciertas enfermedades.

Este momento de prosperidad se vio potenciado con los gobiernos de emperadores competentes como lo fueron Adriano, Antonio Pío y el mismo Marco Aurelio, quienes, además de su función política, fomentaron las artes y las ciencias. Destaca aquí el famoso médico griego Galeno, quien fue testigo y cronista de la aparición de las mencionadas enfermedades producto de la invasión del hombre a espacios vírgenes. Una enfermedad que, gracias a los registros de Galeno, podemos suponer que fue la viruela (Variola major).

Según la tradición romana, el inicio de la llegada de nuevas e implacables enfermedades se debió a cierto sacrilegio de las legiones imperiales cuando destruyeron la ciudad de Seleucia del Tigris (Mesopotamia) y saquearon el templo del dios Apolo. De allí que nuestro autor titule su tercer capítulo como "La venganza de Apolo". Curiosamente, desde los tiempos de las polis griegas, Apolo fue un dios asociado a las plagas, pues este las lanzaba como flechas con su arco.

¿Pero cuál es la verdad sobre la aparición de esta peste que se volvió pandémica? Al parecer, sus orígenes provienen de mucho más al este de Seleucia y están relacionados con la gran ruta comercial que Roma tenía con el Lejano Oriente. Una ruta que se iniciaba en el Imperio chino de la dinastía Han, atravesaba por el mar tanto el sudeste asiático como la India y llegaba a territorio imperial vía la costa oriental de África y el mar Rojo. 
En esta parte del texto se nos deja claro que un imperio en expansión se encontró con una enfermedad infecciosa desconocida y de rápida transmisión gracias a la red de caminos terrestres y rutas marítimas, así como ciudades abarrotadas de gente producto del crecimiento demográfico presentado en el capítulo previo. En resumen, la combinación de los logros del imperio con una enfermedad infecciosa - aparecida fortuitamente o no-y una población con un gran estrés fisiológico llevaría a Roma a su primer descalabro y al inicio de su descenso. Una total paradoja de la historia.

Aproximadamente catorce millones de ciudadanos del imperio fallecieron a causa de lo que Galeno denominó la "gran pestilencia". La caída de mano de obra derrumbó la economía agrícola, lo que a su vez produjo hambruna y una reducción en el reclutamiento de tropas para un ejército que era el sostén del Estado. Pese a todo esto, Roma resistió, aunque era el inicio del fin.

En su cuarto capítulo, "La vejez del mundo", Harper sostiene que el contexto político de Roma en el siglo III no solo se reduce a la famosa crisis política de emperadores fugaces que constantemente tomaban el poder por la fuerza produciendo inestabilidad, sino que a eso se le agrega el fin de los tiempos de un clima excepcional y el inicio del denominado "periodo transicional romano", asociado al fenómeno El Niño-Oscilación del Sur (ENSO, por sus siglas en inglés) y las consecuentes sequías. Finalmente, la gota que rebalsa el vaso aparece en 249 d. C., cuando el obispo cristiano Cipriano registra la aparición de una nueva epidemia proveniente de la actual Etiopía; tanto los comentarios de Cipriano como otros textos de la época hacen pensar a nuestro autor que esta nueva enfermedad podría tratarse del ébola, que se trasladó desde alguna especie animal no identificada a los hombres, quizá como parte del comercio de especies salvajes que Roma necesitaba para sus grandes espectáculos.

Esta enfermedad se expandió por todo el imperio, debilitando nuevamente la estructura del Estado tanto en su aparato productivo como en lo que correspondía a sus tropas, las cuales no pudieron detener los embates de los germanos en su frontera norte, ni la invasión persa en su frontera oriental. Por otro lado, el cristianismo aprovechó la debilitada credibilidad del paganismo clásico para reemplazarlo en una población desesperada por encontrar respuestas al caos del momento. Solo fue la aparición de un nuevo tipo de gobernantes lo que salvó y mantuvo unido al imperio; los emperadoressoldados oriundos de las provincias danubianas pusieron fin al gobierno de una élite aristocrática-senatorial italiana surgida desde los tiempos de la Roma republicana e iniciaron el gobierno de una élite militar provincial.

Lamentablemente para el imperio - lo menciona el capítulo 5, "La rápida rueda de la fortuna"-, ciertos acontecimientos se asociaron para provocar una "tormenta perfecta" a inicios del siglo $v$ de la era cristiana. Oscilaciones de vientos en el Atlántico Norte llevaron a que la fértil estepa centroasiática tuviera un proceso de aridez que provocó 
la migración forzada de pueblos nómades-ganaderos que conocemos como los hunos. Este pueblo de indomables jinetes atravesó en pocos años miles de kilómetros hasta entrar al este de Europa empujando a comunidades de origen germano sobre las fronteras romanas, las cuales, pese a contar aún con unas fuerzas armadas excepcionales, no pudieron evitar una invasión de tal magnitud y en diferentes frentes. Este fue el fin de la Roma occidental y el inicio del esplendor de la parte oriental, también conocida como Imperio bizantino.

Es justamente Bizancio el corazón del capítulo 6, denominado "La prensa de la ira". Esta parte nos sitúa en la Constantinopla de tiempos de Justiniano, emperador que intentó recuperar los territorios occidentales del imperio, pero fracasó debido a la aparición de una nueva enfermedad que se transformó en pandemia: la peste bubónica. Dicha peste, producto de la bacteria Yersinia pestis, se propagó explosivamente a partir de 541 d. C., siguiendo la ruta comercial de los cereales que tenían como punto de partida los graneros egipcios y culminaba en sus similares constantinopolitanos. La bacteria se expandió de una forma muy particular; su origen, se especula, fue el Oriente Extremo, en donde, por la combinación de erupciones volcánicas y el fenómeno ENSO, roedores silvestres portadores de pulgas (que a su vez contenían la bacteria mencionada) tuvieron contacto con las ratas que siguieron las caravanas tanto terrestres como marítimas que formaban parte de la famosa Ruta de la Seda.

De esta manera tan insólita, la peste negra "invadió" el Mediterráneo y acabó por lo menos con un 40 \% de la población de Constantinopla y otras grandes ciudades del imperio oriental; además, cruzó las fronteras bizantinas y se expandió en toda Europa occidental y el Imperio persa sasánida. La peste detuvo el crecimiento bizantino y el de su rival iraní, dando paso al nacimiento y expansión del islam tras la llegada de Mahoma en la primera mitad del siglo VI, lo que significó para algunos cristianos el inicio del fin de los tiempos o, como lo denomina Harper en su último capítulo, "El día del juicio final".

Toda la obra hasta ahora descrita fue publicada tres años antes de los acontecimientos que sorpresivamente hoy en día azotan a nuestro planeta. La llegada de una enfermedad que proviene del mundo animal y que debido a la depredación de las zonas naturales llegó a las grandes urbes, primero de China y luego, por la globalización, a cada rincón del planeta. En estos momentos la vida y la cultura, como las conocemos, están dando un giro por ahora insospechado, tanto como lo fue la decadencia y el fin de Roma en su momento. Los romanos, así como nosotros, los ciudadanos de la "aldea global", nunca sospechamos que la combinación de nuestros logros y desaciertos como civilización, sumados a eventos naturales que escapan de nuestro control, podrían llevarnos cerca del fin de un momento que pensamos eterno y al inicio de algo aún más nebuloso. 